Alicja Stępień-Kuczyńska

Uniwersytet Łódzki

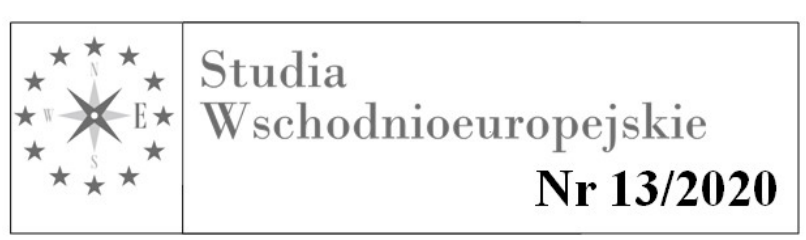

\title{
System polityczny, zmiana, wyzwania dla politologii
}

$\mathrm{O}$ upadku systemu zimnowojennego, dynamiczne zmiany dokonują się nie tylko W sferze systemów politycznych poszczególnych państw, ale poza systemem, w otoczeniu systemów i oddziałują na systemy polityczne. By odpowiedzieć na szereg problemów z tym związanych, warto przypomnieć sobie refleksje Davida Eastona, który wskazywał na wpływ różnorodnych czynników zewnętrznych na system polityczny, doprowadzających do jego modyfikacji, a nawet zmiany. O ile czynniki wewnątrz systemu możemy zmierzyć i zbadać, poprzez wykorzystanie znanych nam narzędzi, i to przez wiele lat robiliśmy, o tyle czynniki otoczenia zewnętrznego wpływające na system, zwykle określaliśmy, ale wiele z nich niedostatecznie analizowaliśmy, lub co obserwujemy obecnie, nie byliśmy w stanie przewidzieć ich znaczenia i poziomu wpływu.

Narastający nieład międzynarodowy, pogłębiająca się niestabilność gospodarcza w świecie, zmniejszają poczucie bezpieczeństwa obywateli. Czekają nas „płynne czasy, życie w poczuciu niepewności” pisał Zygmunt Bauman, podkreślając, że powinniśmy się do tego przyzwyczaić i w pewnym stopniu na to przygotować ${ }^{1}$. Immanuel Wallerstein w połowie lat 90. minionego wieku ostrzegał: „Główny problem dotyczy zaufania. Komu będziemy wierzyć w świecie bez porządku, w świecie kolosalnej ekonomicznej nieokreśloności, w świecie, w którym przyszłość jest nieprzewidywalna. Wczoraj większość ludzi wierzyła w państwo..."2. Ale czy to możliwe dziś? Istnienie zagrożeń, które w coraz większym stopniu towarzyszą naszej egzystencji, a może coraz bardziej je odczuwamy, nie oznaczają, iż ,umiemy sobie radzić z nimi w skali globalnej, nie posiadamy globalnych środków zaradczych, gdyż nie ma czynnika - pisał E. Wnuk-Lipiński- który takie środki mógłby obmyśleć i wprowadzić w życie w sposób obowiązujący na całym globie"3. Obowiązek ten

\footnotetext{
${ }^{1}$ Także A. Giddens był przekonany, że w świecie późnej nowoczesności jesteśmy narażeni na „...ogólną atmosferę niepewności, która niepokoi jednostkę...skazuje każdego na różne mniej lub bardziej znaczące sytuacje kryzysowe...", A. Giddens, Nowoczesność i tożsamość, s.167.

${ }^{2}$ I. Wallerstein, After Liberalism, The New Press, 1995, New York, s. 44.

${ }^{3}$ E. Wnuk-Lipiński, Świat międzyepoki, globalizacja, demokracja, państwo narodowe, Kraków 2004, s. 66.
} 
spada na państwo, którego rolą jest m.in. zapewnienie obywatelom bezpieczeństwa i poczucia stabilizacji. Władza ma do swej dyspozycji cały arsenał środków, mechanizmów, instytucji i oczywiście ludzi, by to realizować. Doświadczenia społeczeństw z walki z globalną pandemią koronawirusa COVID-19, wskazują jednak, jak trudno jest poradzić sobie z niespodziewanymi problemami. Niezależnie od reżimu, rządzący, zmuszeni są podporządkować swoje działania zwiększeniu bezpieczeństwa obywateli. W systemach stabilnych demokracji, zwykle rezygnują z doraźnych politycznych korzyści, np. wcześniej zaplanowanych wyborów, referendów. Okres pandemii wymaga bowiem zmiany akcentów w toczącej się politycznej konfrontacji. Jest to dla rządzących zawsze obowiązek, ale i szansa, wykazania się organizacyjną sprawnością, umiejętnością pokonywania sytuacji kryzysowych, troską o obywateli. Ograniczenia, restrykcje wprowadza się w taki sposób, by zachować niezbędny balans między interesami obywateli, a rysującym się na horyzoncie kryzysem. Ale też można obserwować i drugi sposób postępowania rządzących, w którym to traktują oni walkę z pandemią w sposób instrumentalny, jako środek do wzmocnienia swojej pozycji, poszerzania prerogatyw, wywierania nacisku na opozycję i jej marginalizowania. „Autokraci, - stwierdza D. Ziblatt tak lubią takie sytuacje, bo one zamykają usta krytykom, a zwłaszcza politycznym rywalom. W takich okolicznościach, zwłaszcza na początku, przerażeni ludzie stoją po stronie władzy"4. Niewątpliwie, sytuacja zagrożenia stwarza dużo większe możliwości politycznego działania dla rządzących, niż dla opozycji, mającej ograniczony dostęp do tradycyjnych mediów; choć sieć pozostaje otwarta, jednak zalew informacji utrudnia „przebicie się” z opozycyjnym przekazem. Inną kwestią jest na ile propozycje opozycji okażą się interesujące dla obywateli i budowany przez nią przekaz, będzie stanowił alternatywę dla rządowych działań. Tam, gdzie konfrontacyjność dominowała w systemie politycznym, trudno się spodziewać, żeby rządzący, pod wpływem ekstremalnej sytuacji i czując ewentualne zagrożenie dla własnej pozycji ( co może nastąpić jeśli koszty walki z zagrożeniem okażą się wysokie), rozpoczęli dialog z opozycją i ,,przestawili” się na działania konsensualne. Wprost przeciwnie, postarają się w maksymalnym stopniu wykorzystać szansę wzmocnienia swojej pozycji, a marginalizowanie opozycji jest środkiem dla osiągnięcia tego celu. Sparaliżowany zazwyczaj parlament, nie wypełnia podstawowych funkcji, stanowienia prawa i kontroli, staje się areną drugorzędnych konfrontacji. Publiczne starcia między politykami mają charakter powszechny, jednak toczą się, obok obywateli i ich problemów. Wymuszona izolacja ludzi zamkniętych w domach, na czas bliżej nieokreślony, daje

\footnotetext{
${ }^{4}$ Rozmowa J. Żakowskiego z prof. D. Ziblattem, „Polityka” z dnia 24032020.
} 
możliwość zwielokrotnienia przekazu, kumuluje zagrożenia w świadomości jednostki i zmusza obywateli niejako do akceptacji działań rządzących. Zakaz zgromadzeń, restrykcje, powszechne ograniczenia, wzmacniają poczucie braku bezpieczeństwa. W nowej sytuacji wywołanej pandemią, bez wątpienia możemy sprawdzić jaki jest obraz systemu politycznego w danym państwie, jaka jest sprawność rządzących, skuteczność działania instytucji. Jest to niewątpliwie próba dla państwa demokratycznego, w której wyniku będziemy bliżsi odpowiedzi, czy w systemie mamy więcej dahlowskiej poliarchii, czy jej imitacji?

Pandemia przyniosła śmierć setkom, tysiącom ludzi na całym świecie, ale czy, i w jakim stopniu zmieni świat i systemy polityczne? Marcin Król, na jednym z portali społecznościowych, w tym okresie podzielił się refleksją, iż po pandemii świat, jaki dotychczas znaliśmy, odejdzie w niepamięć. Prognozował nawet, że narastająca w społeczeństwie frustracja może doprowadzić do buntów, ponieważ kryzys, który jest nieunikniony, doprowadzi do pojawienia się olbrzymiej liczby „ludzi zbędnych”5. Ludzie ci, tracą jak w okresie transformacji, pracę i środki do życia, mogą stanowić grupę nacisku na rządzących i system, domagać się niezbędnych zmian, równego dostępu do dóbr, gwarancji socjalnych. Ulegną wzmocnieniu podziały socjopolityczne. Trudno obecnie ocenić, w jakim stopniu, ta sytuacja wywoła zmianę? Jak głęboka może być to zmiana? Czy wpłynie na destabilizację systemu, zmianę rządów, zmianę elit? Jest to więc pytanie, co wydarzy się po pandemii?

Jednym $\mathrm{z}$ najczęściej powtarzających się dziś pytań to: $\mathrm{w}$ jaki sposób światowa pandemia koronawirusa COVID-19 wpłynie na sytuację ekonomiczną w świecie, czy doprowadzi do globalnego kryzysu finansowego i gospodarczego? Jak wpłynie to na działania najbardziej wpływowych transnarodowych korporacji? Zamknięcie granic państwowych i restrykcje wprowadzane przez poszczególne państwa, wykazały, że dotychczas swobodny dostęp do przepływu towarów, usług i ludzi został ograniczony, ze względu na normy bezpieczeństwa. Wprawdzie poszczególne państwa sięgają po programy pomocowe dla podmiotów gospodarczych, jednak ze względu na szczupłość środków, dotyczy to ograniczonego zakresu działań i odnosi się głównie do chęci ratowania małych firm i sektora usług. W jednych państwach konsensus i porozumienie z siłami opozycji ułatwiają wprowadzanie działań ochronnych, w innych np. w regionie Europy Środkowej i Wschodniej, w której rządzący dysponują ograniczonymi środkami finansowymi, zaś konsensus elit nie jest podstawą procesu rządzenia, w państwach tych prowadzenie działań

\footnotetext{
${ }^{5}$ M. Król, wypowiedź dla kobieta.wp.pl , (30.03.2020).
} 
ochronnych jest ograniczone i niestety dużo mniej efektywne. Czas walki z epidemią, niestety nie przeszkodził rządzącym w zwiększaniu uprawnień władzy wykonawczej i ograniczaniu wpływu opozycji na proces stanowienia prawa i rządzenia państwem, ogranicza się prawa obywatelskie, prawa pracownicze, zmienia ustawodawstwo wyborcze ${ }^{6}$. Zasadne zatem jest postawienie problemu, w jaki sposób zaistniała sytuacja związana pandemią wpłynie na systemy polityczne poszczególnych państw? Czy zwiększy aktywność obywateli i poczucie więzów między nimi? Czy wprost przeciwnie, poszerzy atrybuty władzy i ograniczy prawa obywateli i sfery wolności obywatelskich, w imię utrzymania powszechnego bezpieczeństwa? Dziś, kiedy znaczenie bezpieczeństwa w skali globalnej, w skali państwa i jednostki jest szczególnie ważne, ze względu na liczne, rosnące zagrożenia, stanowi to oczywisty priorytet, ale może być wykorzystywane instrumentalnie przez rządzących w procesie sprawowania władzy. Tym bardziej, że społeczna kontrola, właśnie nad tą sferą działalności władzy jest utrudniona. „Państwo jest jedyną instytucją, która dysponuje władzą i instrumentami potrzebnymi do organizowania powszechnych świadczeń społecznych oraz ograniczania nierówności dochodów i zamożności w imię dobra całej zbiorowości...Państwo jest też jedynym gwarantem poczucia bezpieczeństwa jednostek i grup społecznych przed niepodlegającymi żadnym regulacjom globalnymi siłami i zagrożeniami"”. Zależność obywateli od państwa jest oczywista „od usług i świadczeń organizowanych przez państwo" ${ }^{\text {. }}$. Jak zatem kształtować niezbędne relacje rządzących z rządzonymi, gdy poziom zaufania do elit władzy jest niski? Badania CBOS w 2019r. potwierdzają, że prawie $60 \%$ obywateli uważa, że nie ma wpływu na sprawy publiczne ${ }^{9}$. Niska w dalszym ciągu frekwencja wyborcza, powoduje, że uczestnictwo w wyborach nie jest ,wystarczającym powodem, by stwarzać poczucie trwałego oddziaływania na sprawy kraju”"10. Od skali skutków kryzysu w

\footnotetext{
${ }^{6}$ Sejm obradował w ostatnich dniach marca nad ustawą specjalną tzw. „tarczą antykryzysową”, gdzie zupełnie niezasadnie zamieszczono zmiany w kodeksie wyborczym, przewidujące głosowanie korespondencyjne dla wszystkich obywateli, motywując to sytuacją epidemii. Ponad 70 - 80\% obywateli była przeciwna utrzymaniu terminu wyborów prezydenckich 10 maja. Ostatecznie wybory nie odbędą się w tym terminie, ale czy będą legitymizowane?

${ }^{7}$ S. Bieleń, Czas próby w stosunkach międzynarodowych. Miscellanea, Warszawa 2017, s. 145.

${ }^{8}$ E. Wnuk-Lipiński, Świat międzyepoki. Globalizacja, demokracja, państwo narodowe, Kraków 2004. s. 171.

${ }^{9}$ Poczucie wptywu na sprawy publiczne. Komunikat z badań nr.27/2020. Wśród osób przekonanych o tym, że mają wpływ na sprawy kraju przeważają ludzie młodzi, wykształceni, o poglądach prawicowych. Nastąpił wzrost o $5 \% \mathrm{w}$ tej grupie w porównaniu z badaniami przeprowadzanymi w poprzednim roku, jest to wskaźnik najwyższy od 1992r. za: https://www.cbos.pl/SPISCOM.POL/2020/K_027_20PDF (7.04.2020).

${ }^{10} \mathrm{~W}$ roku 2004 badania potwierdzały, iż 83\% respondentów nie miało poczucia wpływu na sprawy kraju, Por. Poczucie wptywu na sprawy publiczne. Komunikat $\mathrm{z}$ badań 2004, za: https://www.cbos.pl/SPISCOM.POL/2004K 101 04.PDF i https://www.cbos.pl/SPISCOM.POL/2018K 033 18.PDF (1.04.2020)
} 
sferze gospodarczej, społecznej, będą zależeć zmiany polityczne. W systemie politycznym każdego państwa to oddziaływanie może być inne. Jakie siły wzmocnią swoją pozycję? Uda się to rządzącym, opozycji, czy może strukturom społecznym, grupom jeszcze nieaktywnym w systemie politycznym? Jak zachowają się w tej sytuacji rządzący, opozycja, całe społeczeństwo? Czy można mieć nadzieję, że ci, którzy zdobędą się na pokierowanie publiczną debatą, postawią sobie dalekosiężne cele uzdrowienia państwa i jego systemu, gospodarki, stosunków społecznych? Czy odnowione lub nowe elity, podejmą próbę nowej transformacji, otwartej na dialog ze społeczeństwem, pod hasłem równego dostępu do dóbr? Może to być unikalna szansa upodmiotowienia obywateli w relacjach $\mathrm{z}$ władzą, w których sprawujący władzę mogliby choć trochę realizować weberowskie hasła polityki jako służby $i$ jako powołania.

Z pewnością rola niedocenianych lub wręcz nieznanych czynników wpływających na system, będzie w przyszłości rosnąca, dlatego tak istotne jest wypracowanie relacji i instrumentów, które by czynniki te były w stanie w miarę wcześnie rozpoznać i w miarę skutecznie niwelować, bądź im przeciwdziałać.

Jeśli rzeczywiście jesteśmy u progu zmian, zaś kryzys wywołany pandemią może wywołać wielorakie skutki, należy podjąć refleksje i badania pogłębione nad zmianą! Zmiana systemowa, jaka dokonała się w państwach regionu Europy Środkowej i Wschodniej przełomu lat 80/90 minionego wieku, powinna nas wiele nauczyć. Dzisiejsze problemy z globalną pandemią, jedynie uwidoczniły narastające zjawiska. Okres „zimnej wojny” został zamknięty przez polityków niezwykle pośpiesznie, zaś dynamika ówczesnych procesów w skali międzynarodowej, globalnej, nie skutkowała dostateczną refleksją co do przyszłości świata, jego stabilizacji i zapewnienia bezpieczeństwa. Znacząca dynamika służyła zmianie, ale nie służyła stabilizacji sytuacji w świecie ${ }^{11}$. Dodatkowo, w państwach regionu Środkowej i Wschodniej Europy procesy transformacji politycznej, gospodarczej nakładały się na procesy integracji i globalizacji, co z jednej strony było zjawiskiem pożądanym i obiektywnie koniecznym, z drugiej jednak, wymagało ogromnego wysiłku obywateli tych państw,

\footnotetext{
${ }^{11}$ Warto w tym miejscu przypomnieć stwierdzenie I. Wallersteina, że wydarzenia 89r świadczyły nie tylko o krachu ideologii komunistycznej, ale i o krachu liberalizmu, świat wchodził w epokę postliberalną. „,czas który nastąpił po liberalizmie będzie to czas ostrych walk politycznych". I Wallerstein, After Liberalism, The New Press, New York 1995, ss.3 i n. Autor przewiduje „czas od 1990 po 2025/50 najprawdopodobniej, będzie się charakteryzował deficytem pokoju, stabilizacji i poszanowania prawa", op. cit. ss. 29. Na ten temat też S. Huntington, Trzecia fala demokratyzacji, Warszawa 1995, Linz J.J. Stepan A., Problems of Democratic Transition and Consolidation: Southern Europe, South America and Post-Communist Europe, BaltimoreLondon 1996.
} 
przystosowania się do reguł im dotychczas nieznanych. Z pewnością było wyzwaniem dla transformujących się społeczeństw! Pojawiła się niezwykła presja na obywateli i na elity, by nie tylko zmiany dokonać, ale by ją utrwalić. Z perspektywy czasu wiemy, że jednym z ważnych problemów, którego nie udało się rozwiązać, była kwestia ochrony obywateli przed skutkami zmiany ${ }^{12}$. W trakcie każdej zmiany, sfera społeczna jest szczególnie narażona na destabilizację. Wysokie koszty transformacji, stały się zbiegiem czasu, coraz trudniejsze do zaakceptowania przez obywateli.

Po 30 latach w polskim systemie politycznym, w okresie rządów PiS, rządzący, eksponują pojęcie ,zmiany”. Mając doświadczenie zmiany z lat 80/90 zasadne jest postawienie pytania: z czym mamy dziś do czynienia? Czy jest to rzeczywista próba zmiany? $\mathrm{W}$ jakim celu jest ona przeprowadzana? Czy nie jest to tylko konfrontacja elit w walce o władzę, w której pojęcie „zmiany” jest traktowane instrumentalnie, populistycznie? W jakim stopniu sytuacja $\mathrm{z}$ pandemią zostanie wykorzystana przez rządzących dla potrzeb przeprowadzenia zapowiadanej ,zmiany”?

W państwach regionu Europy Środkowej i Wschodniej istnieje wiele nabrzmiałych problemów, z którymi mamy do czynienia w systemie politycznym, właściwie od początku transformacji. Wymieńmy niektóre z nich: słabość elementów stabilizujących system polityczny (zmniejszająca się rola partii, negatywny dobór elit, upadek społecznych autorytetów); wzrost roli czynników poza systemem i poszerzanie się „,szarej strefy” (podejmowanie decyzji przez struktury nieformalne, nieprzejrzystość procesu decyzyjnego, instrumentalizacja wyborów itp.); zwiększona polityzacja życia publicznego; niestabilność reguł, ustawodawstwa, brak ciągłości działań politycznych, przy braku konsensusu między rządzącymi a opozycją; próby tworzenia nowych form instytucjonalnych, reform, bez konsensusu politycznego; relatywizacja zachowań i działań; instrumentalne traktowania „demokracji” i ,zmiany” w przestrzeni publicznej; posługiwanie się retoryką populistyczną; wykorzystywanie podziałów socjopolitycznych, a nawet ich pogłębianie, w celu wzmocnienia swojej pozycji politycznej.

\footnotetext{
${ }^{12}$ A. Walicki pisał w jednym $\mathrm{z}$ artykułów: Dla znacznej części społeczeństwa polskiego transformacja była doświadczeniem traumatycznym. Liberałowie - nawet na poziomie retoryki- niedostatecznie brali pod uwagę sytuacje ludzi gorzej sytuowanych...Łączyli to z koncepcją nieuniknionej modernizacji, której koszty trzeba ponieść”, A. Walicki, Mit jedności narodu, w: „Gazeta Wyborcza”, 19-20 sierpnia 2006, także: A. StępieńKuczyńska, Europa Środkowa $i$ Wschodnia-refleksje nad zmiana, w: Polityka $i$ kultura $w$ warunkach ponowoczesności, t. II, Poznań 2018, s. 181-191, por także: Transformacja systemowa w Polsce i krajach postkomunistycznych. Studia i rozprawy, red. M. Chałubiński, Pułtusk 2006, Sztompka P., Socjologia zmiany, Kraków 2005, Wiatr J. Europa pokomunistyczna. Przemiany państw i spoteczeństw po 1989 roku, Warszawa 2006.
} 
Musimy zatem zdawać sobie sprawę, że te elementy, które wpływają niekorzystnie na stabilizację systemu demokratycznego w Polsce, będą dodatkowo wzmacniane przez czynniki destabilizujące pojawiające się w otoczeniu zewnętrznym systemu. Kilka lat temu Anthony Giddens stwierdził: „Żyjemy raczej w świecie wielobiegunowej współpracy miedzy największymi państwami i grupami państw, przerywanej jednak regularnie wybuchami napięć i podziałów"13 Demokracje naszego regionu, szczególnie to odczuwają. Jest to niewątpliwie próba dla gospodarek państw i próba dla ich systemów politycznych. Osłabienie stabilizacji systemów nie tylko w warstwie instytucjonalno-prawnej, ale i przez działanie elit, wpływa na zaprzeczenie dotychczasowym regułom, wartościom wypracowanym w okresie transformacji przełomu lat 80/90.

$\mathrm{Na}$ początku XXI wieku E. Wnuk-Lipiński przewidywał: „Najgłębsze zmiany jakościowe są prawdopodobnie jeszcze przed nami, to zaś, czego świat doświadczył po 1989 roku, można uznać zaledwie za wstęp do czekających nas w pierwszych dekadach XXI wieku dalszych przełomów o charakterze jakościowym, które zasadniczo odmienią nasz dzisiejszy horyzont wyobraźni oraz ujawnią nowe perspektywy i nowe zagrożenia, z którymi radzić będą sobie musiały już następne pokolenia" ${ }^{14}$.

Sytuacja w jakiej znalazły się społeczeństwa, stawia nowe wyzwania przed badaczami różnych dyscyplin i obszarów nauki. Wiele lat temu znakomity historyk Jerzy Topolski pisał „Nauka jest efektem długiego historycznego procesu, który ukonstytuował jej wizerunek jako specyficznego rodzaju aktywności intelektualnej... Aktywność ta winna poszukiwać swojej bazy $\mathrm{w}$ rozumie i doświadczeniu (czy obserwacji), a nie we władzy, to znaczy powinna "produkować" wiedzę, która byłaby obiektywna i weryfikowalna, a zarazem byłaby wiedzą, która pozwala przewidywać i działać zgodnie z tymi przewidywaniami"15. To bardzo ważne i odpowiedzialne zadanie. Potencjał nauki powinien zostać wykorzystany nie tylko w zaistniałej sytuacji, ale przede wszystkim, co jest ważne dla nauk o polityce, w analizie rzeczywiści i tworzeniu zespołów badawczych, które wskażą na kierunki badań w tworzeniu perspektyw dla społeczeństwa.

Co to oznacza dla badań politologicznych w zakresie systemów politycznych? Odniosę się tylko do kilku kwestii.

\footnotetext{
${ }^{13}$ A. Giddens, Europa burzliwy i potężny kontynent, Warszawa 2014, s.25.

${ }^{14}$ E. Wnuk-Lipiński, Świat międzyepoki..., op.cit., s. 7-8.

15 J. Topolski, Historia jako nauka po postmodernizmie, [w:] Pamięć, etyka i historia, E. Domańska (red.), Poznań 2006, s. 31.
} 
Relacje między systemem politycznym a jego otoczeniem zewnętrznym w większym niż dotychczas stopniu będą wyznaczały nasze silniejsze więzy z badaczami innych dyscyplin W ramach nauk o polityce ( po ostatniej zmianie - nauk o polityce i administracji). Mam tu na uwadze konieczność naszego współdziałania $\mathrm{z}$ naukowcami uprawiającymi stosunki międzynarodowe, europeistykę, badania nad mediami. Dziś, trudno sobie wyobrazić, by podejmować refleksje nad systemami politycznymi bez rozumienia szerokiego kontekstu otoczenia zewnętrznego ( $\mathrm{w}$ obszarze globalnym, gospodarczym, społeczno-kulturowym). Korzystać powinniśmy z ich doświadczenia i metod badawczych, by w sposób najbardziej pełny odpowiedzieć na pytania np.: w jaki sposób niestabilność świata, nowe reguły, gry polityczne w wymiarze globalnym, mogą wpływać na systemy polityczne i działania elit w poszczególnych państwach? Ważne jest postawienie w centrum zainteresowania również kwestii bezpieczeństwa, możliwość wzbogacenia badań politologicznych, zwłaszcza w obszarze soft power. Ale także ważne kwestie: Czy więzy nieformalne staną się w większym stopniu potrzebą ludzi w świecie niestabilnym? Jakie to będą więzy? Czy będą budowały ludzką „siłę”, zwiększały sprawczość, wpływały na samoświadomość i samorozwój? Czy obywatele organizując się, często poza systemem, będą potrzebowali tego systemu, i będą skłonni się jemu poddać? Dlaczego w jednych państwach procesy te przebiegają w sposób pokojowy, a w innych stale obywatele domagają się od władzy nowych rozwiązań? I tutaj refleksja politologa splata się niejako z doświadczeniami innych dyscyplin. Bliskość z naukami humanistycznymi jest oczywista. Czy możemy prawidłowo ocenić współczesny system polityczny bez wskazania na analizy historyków, w jaki sposób systemy kształtowały się w przeszłości, jakie czynniki wpływały na jego zmianę i jakie to wywierało skutki? Kwestia władzy, stosunku do niej, szacunku do instytucji państwa; postawy obywatelskie. Wykorzystanie historycznej perspektywy w naszych badaniach jest niezbędne. Rozważania filozofów dotyczące idei, tradycji myśli politycznej, wartości; szukanie związków z badaniami socjologów działania mechanizmu funkcjonowania instytucji w sferze polityki, grup społecznych, organizacji, działań elit w sferze polityki, wreszcie poglądów społecznych; w zakresie psychologii kwestie dotyczące partycypacji społecznej, stosunku do władzy, liderów i ich działań. Relacje między politologią a ekonomią od wielu lat są niezaprzeczalne, ekonomizacja polityki i polityzacja gospodarki, to zjawiska i obszary wiedzy, które powinniśmy badać wspólnie. Warto też zwiększyć naszą otwartość na badania kulturologów, antropologów, religioznawców, ekologów. Tworzenie się tych więzi powinno mieć charakter trwały i inspirujący. W tym kontekście aktualności nabiera postulat I. Wallersteina o 
potrzebie otwartości i przenikania się badań, wypracowywania wspólnych analiz przez naukowców dyscyplin społecznych i humanistycznych ${ }^{16}$.

Także w politologii i dyscyplinach pokrewnych rysuje się konieczność wyznaczenia nowych punktów i doprecyzowania odniesień badań w zakresie relacji z innymi dziedzinami wiedzy, nierzadko odległymi, z którymi politolodzy dotychczas bardziej teoretycznie niż praktycznie współpracowali np. nauki ścisłe, przyrodnicze. Każda z tych dziedzin ma dla politologii wiele do zaoferowania, tak $\mathrm{w}$ odniesieniu do stosowanych metod, jak i wykorzystania tradycji badawczej. Może to mieć realny wpływ z jednej strony na tworzenie zespołów badawczych i rozwijanie interdyscyplinarnych badań, z drugiej strony na szersze zainteresowanie się innych dyscyplin badaniami politologicznymi. W tym sensie postrzegam, że rysuje się nowa szansa dla politologii, z której powinniśmy skorzystać! Pokazać naszą obecność w szukaniu odpowiedzi i pogłębianiu refleksji nad dotychczasową rzeczywistością. Mamy okazję dowieźć, że politolog nie zajmuje się komentowaniem działań polityków i odpowiada niejako na ich zapotrzebowanie, a nauką o polityce, czyli m.in. mechanizmami systemu politycznego i czynnikami stabilizującymi system bądź go destabilizującymi. Szerokie pole badań, które w ostatnim okresie jeszcze się poszerzyło, stanowi niewątpliwie wyzwanie dla politologów, ale i okazję do zaprezentowania swoich możliwości i dokonań.

\section{Streszczenie:}

Autorka podejmuje temat zmiany systemu politycznego pod wpływem uwarunkowań zewnętrznych. Nawiązuje do wątku pandemii, która nawiedziła świat w 2020r. jako czynnika, który może wpłynąć na zmiany w systemie politycznym państw. Autorka odniosła się do doświadczeń zmiany systemów w państwach regionu Europy Środkowej i Wschodniej 80/90. Podkreśliła znaczenie badań naukowych, w tym badań politologicznych, w tym zakresie.

\section{Słowa kluczowe:}

zmiana, system polityczny, politologia

\section{Key words:}

change, political system, political science

\footnotetext{
${ }^{16}$ I. Wallerstein, Analiza systemów-światów, Warszawa 2007, s. 35 i n.
} 


\section{Bibliografia:}

1. Bieleń S., Czas próby w stosunkach międzynarodowych, Warszawa 2017,

2. Giddens A., Europa burzliwy i potężny kontynent, Warszawa 2014.

3. Giddens A., Nowoczesność i tożsamość, Warszawa 2010.

4. Huntington S., Trzecia fala demokratyzacji, Warszawa 1995.

5. Linz J.J. Stepan A., Problems of Democratic Transition and Consolidation: Southern Europe, South America and Post-Communist Europe, Baltimore-London 1996.

6. Topolski J., Historia jako nauka po postmodernizmie, [w:] Pamięć, etyka i historia, red. E. Domańska, Poznań 2006.

7. Wallerstein I., After Liberalism, The New Press, 1995, New York.

8. Wallerstein I., Analiza systemów-światów, Warszawa 2007.

9. Wiatr J., Europa pokomunistyczna. Przemiany państw i społeczeństw po 1989 roku, Warszawa 2006.

10. Wnuk-Lipiński E., Świat międzyepoki, globalizacja, demokracja, państwo narodowe, Kraków 2004. 